\title{
1. Social innovation and its contemporary evolution
}

In this chapter I review the contemporary and multi-disciplinary efforts to define and theorize social innovation. This is not a comprehensive 'map of the jungle' but is more of a meta-review aimed at highlighting the common characteristics across disciplines that many see as defining social innovation: that it is the pursuit of social change, and social change that is significant and consequential, sustainable and ultimately institutionalized. I commence by historically examining when the term first started appearing in literature, and discussing that while this may be a new popular term, it could readily be applied to many historical examples of social change. Social change includes social innovation. I then undertake a meta-review of the many contemporary reviews of social innovation, distilling how different disciplines are conceptualizing social innovation. I interrogate different definitions to identify commonalities and core characteristics of social innovation and use this to develop a defensible construct of social innovation.

\section{EARLY USAGE OF THE TERM 'SOCIAL INNOVATION'}

An early reference to the specific term 'social innovation' in organizational and management studies is by Drucker (1987), a management scholar whose work was widely read and adopted by practitioners and industry. In this article titled 'Social innovation - management's new dimension', Drucker emphasizes the impact of non-technological innovations on the economy and society, giving a range of individual, organizational and social movement examples on how positive societal change and development has occurred. His examples of social innovations include 'the research lab; Eurodollar and commercial paper; mass and mass movement; the farm agent; and management itself as an organized function and Discipline' (Drucker, 1987, p. 29). For example, he describes the innovation of research labs by General Electric, in that they brought together multi-disciplinary teams and focused on connecting science to technology. He also cites the rise of farm agents who helped 
US farmers to improve their productivity (and increase their demand for farm inputs). He argued that social innovation was a novel structural improvement in societal organization, creating new capacities for action and thereby raising overall welfare levels (Benneworth and Cunha, 2015).

Almost ten years later, Kanter, another management scholar, provides the next substantial (and oft-cited) reference to social innovation. In an article in Harvard Business Review titled 'From spare change to real change: the social sector as a beta site for business innovation', Kanter extols the value of businesses solving social problems and addressing unmet social needs - for both business and society. The main argument is for companies to move beyond corporate social responsibility (that is, simply avoiding or reducing negative externalities, or undertaking charitable activities), to actively pursuing social sector problems as a business opportunity: that is, from social responsibility to social innovation. Kanter argues that these innovation and $\mathrm{R} \& \mathrm{D}$ efforts are a strategic business investment like any other, and considers that the private sector needs to play a leading role in creating sustainable change to entrenched social problems. Kanter (1999) cites examples such as a mainstream bank opening a community bank to reach under-served minorities, addressing a social need yet also increasing the bank's customer base. Such an approach is reflected in much of the literature on Bottom-of-the-Pyramid (BoP) markets (for example, Anderson and Markides, 2007; Olsen and Boxenbaum, 2009; Prahalad, 2012; Prahalad and Hammond, 2002).

Kanter also connects social innovation as emerging from necessary cross-sector partnerships, between business, government and non-profit organizations, which are difficult given each domain's different goals and responsibilities and also different measures for what constitutes social impact and value. ${ }^{1}$ Kanter goes on to suggest that the government and non-profit sectors need to develop more business-like 'institutional infrastructure' (1999, p. 126), and that working with these sectors (I emphasize here from the perspective of business) is similar to the difficulties of working in under-developed markets. For example, Kanter (1999, p. 126) suggests 'six characteristics of successful private-public partnerships: a clear business agenda, strong partners committed to change, investment by both parties, rootedness in the user community, links to other community organizations, and a long-term commitment to sustain and replicate the results', which is also echoed in more recent research on cross-sector partnerships, specifically public-private partnerships (Selsky and Parker, 2005, 2010).

While Drucker and Kanter are amongst the earliest specific references to 'social innovation', other authors argue that 'social innovation' is a new label for historical instances of social change, which could also be 
described in contemporary terms as social innovation (McGowan and Westley, 2015; Mulgan, 2006; Tracey and Stott, 2017). Mulgan (2006) gives an array of historical examples of individual social innovators and socially innovative organizations. For example, at the individual level, history is rich with examples of individuals who developed groundbreaking ideas to address problems of the day and, perhaps more importantly, successfully diffused these ideas, compelling adoption, and so greater social and often systemic change. Is Thomas Edison therefore a social innovator? Detailed, historical analyses of Edison's efforts to produce and diffuse the electric light show this individual's ability to understand and engage multiple stakeholders (regulators, competitors, consumers) to develop the necessary system and resulting institutional infrastructure for an electricity system (Hargrave and Van de Ven, 2006), having wide-scale technological and arguably, positive, social impact. In another example, Mulgan (2006) describes Florence Nightingale as a social innovator. Known as a social reformer, this statistician reformed nursing and medical care, and was made famous by reports of her nursing efforts during the Crimean War, and efforts to disseminate medical knowledge in plain language. As Lawrence et al. (2014) note, the role of individuals in managing social innovation is a focus in the growing literature on social entrepreneurship, and also civic entrepreneurship (Elkington and Hartigan, 2008).

At an organizational level, while much of the current focus is on finding new means or mechanisms to collaborate and co-create hybrid solutions to social problems or on creating new organizational forms that encourage the pursuit of financial and social value (Battilana and Lee, 2014), there are some historical organizational forms associated with the notion of social innovation and the pursuit of social change. Mulgan (2006) suggests cooperatives and trade unions are social innovations, being historical organizational forms with a central social purpose, designed to pursue a social mission of improving conditions (of work, of pay, of ownership of capital). For example, cooperatives began in 18thcentury Britain when workers pooled their income to buy materials and food, and were often common in agriculture and farming sectors. There are debates over the earliest recorded cooperative, with claims that the first cooperative was established in 1791 in Scotland. The Fenwick Weavers' Society was established to sell discounted oatmeal to local workers, later expanding to provide savings and loan services and education. Most famously for the cooperative movement was the establishment in 1844 of the Rochdale Equitable Pioneers Society by mill workers in northern England. As Mulgan (2006) describes, as part of its 
establishment it devised eight principles of cooperation: open membership; democratic control; distributing profits to members in proportion to their spending; paying small amounts of interest on capital; political and religious neutrality; cash trading, no credit; promotion of education; and quality goods and services. At the time, cooperatives represented a novel form of organizing to achieve a social purpose.

Another driver and form of social innovation is social movements (Mulgan, 2006). Social movements are a set of opinions and beliefs in a population that represents preferences for changing some elements of the social structure and/or reward distribution of a society (McCarthy and Zald, 1977). They are 'a major vehicle for ordinary people's participation in public politics' (Tilly, 2004), as they seek to resist, undo or carry out social change. As a form of group action (often with organizational structures and strategies), social movements may enable oppressed populations or non-elites to effectively challenge existing systems and institutions and those who lead them. Examples of historical social movements that resulted in social change (with many arguing much change is still to be achieved) are feminism, race equality and environmentalism.

These earliest references to social innovation raise a number of points. That, coming from the organizational and management literature, social innovation was often seen as a business opportunity and mainly concerned with non-technical innovation, to do well and also do good; that social innovation would often involve cross-sector partnerships to address problems but also as the source of innovation itself; and that many historical examples exist of individuals and organizations, and also social movements, that would now be labelled as social innovation. The pursuit of social change is multi-level and often focused on significantly transforming existing ways of organizing and managing.

As a term and concept, social innovation has also attracted the attention of other disciplines, as they seek to become involved in the pursuit of social change. I turn now to reviewing the many recent reviews of social innovation and its application across disciplines to further develop the construct.

\section{UNDERSTANDING SOCIAL INNOVATION ACROSS DISCIPLINES}

While some of the earliest references to social innovation can be found in the organizational and management literature, much early writing on social innovation is in fact located outside academia, published by 
foundations and think-tanks (Mulgan, 2006). Practitioners and policy makers, often frustrated with a lack of progress over many years, and being presented with challenges, such as climate change and persistent poverty, that required collaboration across sectors, and a need to mobilize more funding for solutions, have sought new ways to address social problems. Admittedly this is not an uncommon direction of influence in organizational and management studies, when popular concepts are later examined and theorized. Given its association with social change and addressing large-scale problems, the term has more recently attracted much interest in scholarly communities, and also across a wide range of scholarly communities. For example, in organizational and management studies, social innovation is seen as relating to contemporary ideas of social entrepreneurship, social finance, corporate social responsibility, open innovation, public-private partnerships, inclusive innovation and collective impact (Phills et al., 2008). Beyond organization and management studies, theorizing and application also occurs in urban studies, technology management, sociology, not-for-profit and third sector, public administration and public policy (Edwards-Schachter and Wallace, 2017; Lawrence et al., 2014; Moulaert et al., 2013; Pol and Ville, 2009). Figure 1.1 outlines the rise in articles citing 'social innovation' in the title, abstract or keywords across disciplines.

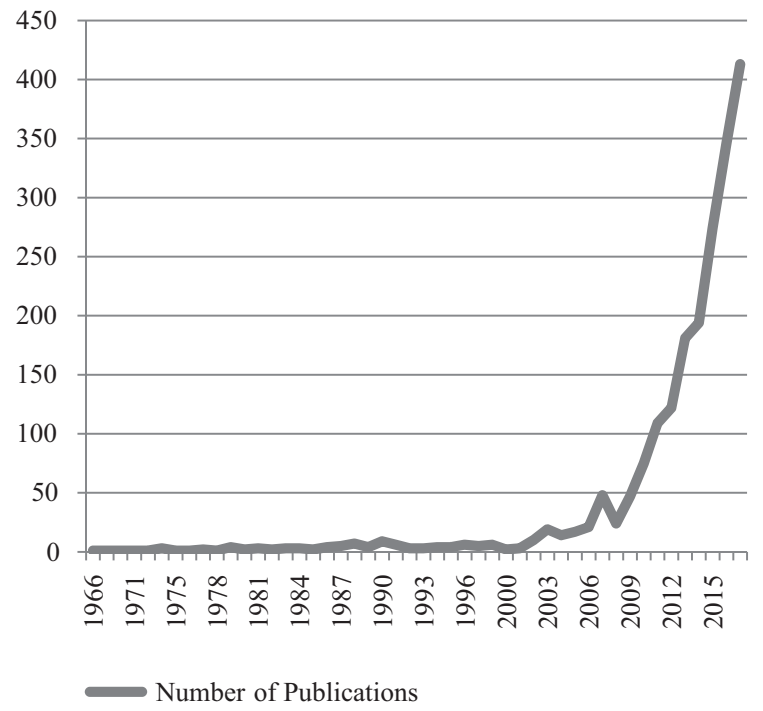

Figure 1.1 Rise in academic publications citing 'social innovation' in title, abstract or keywords 1966-2017 


\section{Seeking a Definition of Social Innovation}

Like any emerging concept or area of activity, much early work fixated on attaining a singular definition and setting definitional boundaries, based on the assumption that conceptual precision and clarity is necessary for the growth of the field (and in directing its growth).

Systematic reviews of the definition of social innovation identified 76 definitions across academic and grey literature, suggesting the term has become an amalgamation of activities, aspirations, ideologies and rationalities, incorporating normative and instrumental meanings, and structural and behavioural patterns of activity (Edwards-Schachter and Wallace, 2017, p. 64). Table 1.1 is a summary combining definitions included in some of the reviews of social innovation and also frequently cited definitions in 'grey' literature that are referred to in scholarly materials, and from organizations with significant influence on the practical deployment of the term.

Across these and many other definitions of social innovation is a mixed focus on social innovation as a process and/or outcome (Cajaiba-Santana, 2014; Edwards-Schachter and Wallace, 2017; Silveira and Zilber, 2017; Van der Have and Rubalcaba, 2016). Raising confusion - is it about the process of generating social value or good, or the ultimate social value produced? Do the ends then justify the means? One of the earlier and oft-cited definitions (in both grey and academic literature) provided by Mulgan (2006, p. 145) describes social innovation as 'the development and implementation of new ideas to meet social needs'. Westley and Antadze (2010, p. 2) offer a more elaborate definition: 'social innovation is any initiative, product, process, programme, project or platform that challenges and over time contributes to changing the defining routines, resources and authority flows of beliefs of the broader social system in which it is introduced; successful social innovations have durability, scale and transformative impact.' The type of resulting change is also an issue for Van Wijk et al. (2018, p. 3), who focus on social innovation as institutional change: 'Social innovation for us describes the agentic, relational, situated and multi-level process to develop, promote and implement novel solutions to social problems in ways that are directed towards producing profound change in institutional contexts.' Across this compilation of definitions, several characteristics of social innovation are fairly consistent: (1) collectivity and the role of understanding social movements and collective action in generating social value; (2) diversity and the role of multi-disciplinary and cross-sector interactions in generating social value; and (3) what I describe as relationality, the role of creating new relational channels and configurations in generating social value. 


\section{Table 1.1 Sample of definitions of social innovation across academic and 'grey' literature (in chronological order)}

Source
Kanter, R.M. (1999). From spare
change to real change. The social
sector as beta site for business
innovation. Harvard Business
Review, 77(3), 122-32.
OECD (2000). OECD LEED Forum
on Social Innovations.

Mumford, M.D. (2002). Social innovation: ten cases from Benjamin Franklin. Creativity Research Journal, 14(2), 253-66.

Phills, J.A.J., Deiglmeier, K. and Miller, D.T. (2008). Rediscovering social innovation. Stanford Social Innovation Review, 6(4), 34-43.

\section{Definition}

A partnership between private enterprise and public interest that produces profitable and sustainable change for both sides; innovations that have business as well as community payoffs.

The working definition of social innovation adopted in the framework of the Forum on Social Innovations was that it 'can concern conceptual, process or product change, organisational change and changes in financing, and can deal with new relationships with stakeholders and territories'. 'Social innovation' seeks new answers to social problems by:

- Identifying and delivering new services that improve the quality of life of individuals and communities.

- Identifying and implementing new labour market integration processes, new competencies, new jobs, and new forms of participation, as diverse elements that each contribute to improving the position of individuals in the workforce. Social innovations can therefore be seen as dealing with the welfare of individuals and communities, both as consumers and producers.

'The term social innovation ... refers to the generation and implementation of new ideas about how people should organise interpersonal activities, or social interactions, to meet one or more common goals. As with other forms of innovation, the products resulting from social innovation may vary with regard to their breadth and impact.' (p. 253)

A novel solution to a social problem that is more effective, efficient, sustainable ... than existing solutions and for which the value created accrues primarily to society as a whole rather than private individuals 


Source
Nicholls, A. and Murdock, A. (eds)
(2012). Social Innovation. Blurring
Boundaries to Reconfigure Markets.
New York: Palgrave Macmillan.

Cajaiba-Santana, G. (2014). Social innovation: moving the field forward. A conceptual framework. Technological Forecasting and Social Change, 82, 42-51.

Voorberg, W.H., Bekkers, V.J. and Tummers, L.G. (2015). A systematic review of co-creation and co-production: embarking on the social innovation journey. Public Management Review, 17(9), 1333-57.

World Economic Forum (2013). Breaking the binary: policy guide to scaling social innovation. WEF.
Definition

Social innovation is defined here as varying levels of deliberative change that aim to address suboptimal issues in the production, availability, and consumption of public goods defined as that which is broadly of societal benefit within a particular normative and culturally contingent context. What is abundantly clear is that social innovation is complex and multi-faceted.

Social innovations are new social practices created from collective, intentional, and goal-oriented actions aimed at prompting social change through the reconfiguration of how social goals are accomplished. They are 'a collective creation of new legitimated social practices aiming at social change'.

Social innovation as the creation of long-lasting outcomes that aim to address societal needs by fundamentally changing the relationships, positions and rules between the involved stakeholders, through an open process of participation, exchange and collaboration with relevant stakeholders, including end-users.

The application of innovative, practical, sustainable, business-like approaches that achieve positive social and/or environmental change, with an emphasis on low-income or underserved populations.

\section{Crossing Disciplines: Reviewing the Reviews of Social Innovation}

In recent years a stream of studies have emerged attempting to review the plethora of other studies (mostly in the academic sphere) which cite the concept of social innovation or report to be theorizing social innovation and mapping the current and future theoretical landscape. As a popular and expanding concept, some early reviews of social innovation highlighted the diversity of disciplines interested in the topic and a consequent and growing fragmentation around the scope and meaning of social innovation (Cajaiba-Santana, 2014; Edwards-Schachter and Wallace, 2017; Phillips et al., 2015; Silveira and Zilber, 2017; Van der Have 
and Rubalcaba, 2016; see Chapter 1). Many early definitions tried to encompass a variety of views, often sociological in nature and incorporating aspects of both structure and agency (Van der Have and Rubalcaba, 2016). Reviews include Silveira and Zilber's (2017) bibliometric analysis of social innovation, Van der Have and Rubalcaba's (2016) network and bibliometric analysis, Cajaiba-Santana's (2013) structural and institutional summary of social innovation, and content analysis of key terms and understandings associated with social innovation.

In Pol and Ville's (2009) early review and discussion of the term, they describe its mixed emergence in varied academic but especially practitioner literature (as noted in definitions above). This review highlights the concept of social innovation as being related to institutional change, social purposes, the public good, and not necessarily delivered by market mechanisms (as social innovation is often perceived as addressing needs that have been ignored by the market). Pol and Ville (2009) describe social innovation in comparison to business innovation, offering a more economic conceptualization: where the former pursues social impact, the latter pursues increased profitability. They do raise issues with the ultimate outcome of social innovation, that is improved quality of life, noting that there is no agreed definition here, and the complexities that occur when considering the relationship between improvements at the individual level versus the collective level. This starts to raise the issue of social value capture and (re)distribution when it comes to conceptualizing social innovation.

Cajaiba-Santana (2014) is the next academic article to review the growing interest in social innovation, suggesting there exist two main approaches to social innovation: agentic-centred (closely related to the literature on social entrepreneurship and the role of the individual 'hero' change agent), and structuralist (referring to the social structures in which these agents operate). While the review is less systematic and uses a mix of sociological and institutional theories, it does importantly suggest the connection between social innovation and institutional change, and the necessary interactions between structure and agency to make this happen.

Two years later, Van der Have and Rubalcaba (2016) conduct a more systematic network and bibliometric analysis of the expanding scholarly literature on social innovation, focusing on the relationship to innovation studies more generally. They suggest social innovation is more of an innovation paradigm than a separate category of innovation, referring to 'a large revitalization of the social aspects involved in any kind of innovation, technological innovation included' (Van der Have and Rubalcaba, 2016). They review the concept by creating a data set of all articles published between 1986 and 2013, resulting in 172 unique publications. 
In their bibliometric study of these articles (where a relationship is constructed between cited references or topic keywords), they produce a map of the relationships and most influential articles, and identify different disciplinary approaches from psychology, sociology, urban studies and management and business. This initially reveals two important foundational articles that are highly cited and therefore shaping the concept of social innovation: Swyngedouw's (2005) paper on grassroots innovation and the need for more innovative and participatory governance structures, and Ramirez's (1999) strategy article on value creation and specifically value co-production as social innovation.

The results of Van der Have and Rubalcaba's (2016) bibliometric study also reveal four main disciplinary clusters for the study of social innovation. First, 'creativity research', a distant and rather unconnected cluster that is predominately based on the one popular article by Mumford (2002). This describes 10 varied empirical examples of social innovations, emphasizing social innovation as about social relationships and social organization. Second, a cluster described as 'community psychology', underpinned by a group of articles examining social innovation and behavioural change (Hazel and Onaga, 2003). Third, a large cluster described as 'local development', encompassing studies of communities or neighbourhoods, cities and regions, and both urban and rural settings (Van der Have and Rubalcaba, 2016, p. 1928). This cluster focuses on empowering citizens, participation and inclusion, and the role of governance. Two influential works underpin this cluster: Swyngedouw (2005) and Moulaert et al. (2005) on local innovation, both published in a special issue of the journal Urban Studies.

The largest cluster identified by Van der Have and Rubalcaba's (2016) bibliometric study is labelled as 'social and societal challenges', and focuses on innovative solutions as outcomes to social and technical challenges. Grouped within this cluster is work considering cross-sector alliances and collaborations, social entrepreneurship, and value coproduction (Ramirez, 1999). While this review shows that social innovation has a 'young and unsettled history' (2016, p. 1932), the authors identify two core conceptual elements for understanding social innovation, in that 'it encompasses: (1) a change in social relationships, - systems, or - structures, and (2) such changes serve a shared human need/goal or solve a socially relevant problem' (2016, p. 1932).

Another review of social innovation is provided by Edwards-Schachter and Wallace's (2017) content analysis of key terms and understandings. In this study, they produce a data set of 252 definitions of 'social innovation', and use semantic network analysis to identify and examine key terms and connections. Three main clusters emerge, defining social 
innovation as: processes of social change, sustainable development (linking development and value), and services sector (linking to social need and quality of life). They describe a rough timeline of the changes in discourse surrounding social innovation, beginning with Drucker's description of social innovation and required organizational change, followed by social innovation being discussed in relation to environmental challenges. There is then a period of two decades (up to the mid-1990s) where social innovation is little used as a term. It then emerges again as a policy and normative concept, further growing in interest with the rise of discussions on social entrepreneurship, hybrid forms, and cross-sector partnerships.

Most comprehensive, at the time of writing, is Silveira and Zilber's (2017) review of social innovation. Similar to Van der Have and Rubalcaba's (2016) study, they also produce a bibliometric study, conducting both citation and co-citation analysis on a dataset of 165 articles that mention 'social innovation' as a keyword. The analysis shows a large uptake of the term post-2010, identifying eight fields across which the articles were published: social sciences, business, computer science, engineering, arts and humanities, economy and finance, energy and environmental science, and psychology. In their co-citation analysis, they produce a network map of the most commonly cited keywords, and also a network map of the most commonly cited articles. By also conducting a factor analysis to classify the articles by their focus, the authors divide the set of publications into three main fields: social innovation, consisting of articles concerned with the definition, clarification and application of the concept; social entrepreneurship, consisting of articles that consider social innovation as a result of entrepreneurial effort; and public policy management, consisting of articles concerned with the relationship between the government and other stakeholders and new relational arrangements to address social problems.

This 'review of reviews' provides a comprehensive analysis of a large and growing set of diverse articles that cite and apply 'social innovation'. It also provides the opportunity to identify key themes in contemporary definitions and application. These are set out in the next section.

\section{Identifying Common Insights of Social Innovation as a Construct}

Recently, Tracey and Stott (2017) propose typologizing social innovation based on different approaches to social change. Here, they suggest that three types of social innovation can be defined through an analysis of the location of the interaction: 
- social entrepreneurship - where social change is created through the founding of new organizations (for example, social enterprises, for profit or non-profit);

- social intrapreneurship - where change is created by leveraging the resources and capabilities of existing or established organizations (that is, inside these organizations);

- social extra-preneurship - where change is created through platforms that support collective effort within and between new and established organizations.

Social entrepreneurship, as defined here, is akin to thinking around individual entrepreneurs with a social mission, often working in the for-profit sector, and developing market-based solutions for social change and positive impact. Social intra-preneurship here is more akin to traditional thinking around corporate social responsibility and shared value (Porter and Kramer, 2011) within corporations and for-profit firms. Within this category, Tracey and Stott (2017) also note the move for public sector agencies to adopt more collective and open processes of innovation when addressing social problems. Such agencies are increasingly using processes of open innovation, where the public and users are involved in co-creation (Randhawa et al., 2017). This may lead to social extra-preneurship as described here, considering the collective and collaborative nature of social innovation, necessary in breaking down silos between the public, private and non-profit sectors and achieving systemic change.

It is the cross-sector work for social innovation, categorized here as social extra-preneurship, that is arguably the most difficult and currently less theorized. What is emphasized in this type of social innovation is that it is an inter-organizational action and activity that 'facilitates alternative combinations of ideas, people, places and resources to address social challenges and make social change' (Tracey and Stott, 2017; see also Algoso, 2015). Activity here may occur between organizations and networks, cultivating the spaces between fields and organizations by building new infrastructure to support social change and social value creation (Logue and Grimes, 2018; see also Chapter 4 in this book).

From across these reviews, and consideration of both academic and 'grey' literature, there are several characteristics that are commonly or frequently attributed to social innovation. ${ }^{2}$ These provide a set of elements or issues on which to examine social innovation, and are as follows: 
- Social value: the main objective of social innovation is improved social outcome that is accrued for collective rather than private benefit.

- Source: it can be driven by individuals, organizations or social movements; these individuals and organizations may be located within existing organizations, outside existing organizations or across organizations (Tracey and Stott, 2017).

- Significance: while social innovation may pursue large-scale system change (or social problems that require system change), it is acknowledged that incremental change can also be transformative in the longer term (Campbell, 2004).

- Collectivity: social innovation often (yet not always) occurs as a collaborative or rather participative process; this is because many of the social (and intractable) problems being addressed cannot be addressed by one organization or one sector alone.

- Diversity: given the above, a diversity of actors and disciplines is often involved in a process of social innovation.

- Relationality: new relational channels or configurations often need to be established and institutionalized as part of these collaborations; however the coordinating infrastructure to achieve this is varied, temporary, and also under-theorized.

These issues and elements inform a construct of social innovation, appearing in different combination and emphasis in the theoretical lenses outlined in this book.

\section{EMERGING TENSIONS AND DEBATES IN SOCIAL INNOVATION}

There are several tensions, some inherent, in this wide-ranging literature theorizing social innovation. I identify the first of these as problemsolution coupling and how decisions are made around problem definition and prioritization, and the consequent selection of solutions to social and environmental problems. This in turn raises the second core tension in social innovation of the power and politics involved in this process of problem and solution identification and action. Another tension is the responsibility for action and change, and the scale of that change. A shift is apparent, moving from a focus on heroic individuals to processes and systems as drivers of social change. This is associated with another tension or issue, the rise of another popular and related term, that of 'inclusive innovation' and 'systems innovation'. 


\section{Problem-Solution Construction and Coupling}

A common concern in the literature on social innovation is that of solving social problems. The social problems of interest are often large-scale and multi-generational, such as climate change, poverty, obesity and homelessness. Yet, as is increasingly observed in the associated social finance and impact investing literature (for example, Logue et al., 2017), deciding on which problem is the priority (when faced with limited resources) and what counts as social impact is problematic and political. The identification, description (especially boundary setting) and prioritization of social problems is in and of itself socially constructed. This means that what constitutes a problem, its boundaries, its effects, and its importance is a process of social negotiation and is not given (Clegg et al., 2006; Lawrence et al., 2014). As such, values, norms and power relations all impact problem and solution definition and their associated coupling. For example, in the charity sector we already see struggles to gain donations for causes that are less 'attractive', widespread or comparatively lack awareness, such as different types of diseases. 'There are particular moral assumptions about who is and is not "worthy" of support - which tend to reflect the values of elites - and shape whether issues become categorized as "problems" (Tracey and Stott, 2017, p. 56). Within the construction of the problem are understandings of responsibility (for example, is it the individual or the failure of the system), resources (does addressing homelessness require more resources for mental health or temporary shelters or public housing stock), and value, such as how much is it worth to society to reduce recidivism rates of prisoners (how to calculate this, and does this contribute to political elections), and so on. Therefore, an important consideration in social innovation is to consider not only the novel solution, but the construction of the problem, and its coupling (relationship) to the solution. 'This shifts the question of what counts as a social problem from being a boundary condition of social innovation scholarship to an integral element of managing social innovation, and consequently a necessary part of the processes and practices examined' (Lawrence et al., 2014, p. 4).

\section{Embeddedness, Power and Politics}

Accompanying the recognition that the social construction of social problems is at the core of social innovation literature and activity, is the recognition of the embeddedness of individuals, organizations and governments in institutionalized social systems and mental models. We know 
from volumes of innovation literature (see Rogers, 1962 for a classic overview) that diffusing a new product, service or way of organizing is extremely difficult as existing incumbents may resist or challenge novel ideas (especially when these challenge the status quo or power relations). More broadly, as Lawrence et al. (2014) describe, 'resistance to change is rooted in people's investments - material (time and money), cognitive (assumptions and values), and relational (social capital and networks) to existing arrangements' and so maintaining the status quo (Lawrence et al., 2014, p. 323). Any process of social innovation is conducted within existing social, organizational and technological structures that may both enable and constrain them. While seemingly abstract, this reinforces the understanding that a novel solution to a social problem is likely to involve (or invoke) a connected set of actors, processes and practices, achieving change or the creation of social value by reconfiguring social, discursive and material relations (Lawrence et al., 2014). Furthermore, that the social value created, and its distribution, is also a negotiated and so inherently political process; 'the impacts of social innovation are never "ethically neutral"" (Lawrence et al., 2014, p. 325). As will be discussed in detail in Chapter 4, an institutional theory lens is valuable for examining social innovation, as it highlights the importance of the established social arrangements and the institutions and institutional infrastructure that enable and reinforce them. These institutions may be the source of intractable social problems, such that novel solutions will require associated change in these institutions and deeply held meaning and power structures.

\section{From the Social Innovation 'Hero' Individual to Cross-sector Processes and Systems Thinking}

Social innovation as a concept has been rapidly embraced across business and management literature and is often associated with broader processes of innovation and entrepreneurship. As such, the more dominant and current understandings of social innovation have viewed the phenomenon through this lens, in particular associating social innovation with product innovation processes and the conceptualization of the 'hero' and lone operating entrepreneur. However, just as the entrepreneurship literature has moved away from worshipping individual entrepreneurs (the likes of Richard Branson, Virgin CEO Founder, or even US President Donald Trump) and considering entrepreneurship as based on personality traits, to adopting more of a process and systems change approach, a similar shift has occurred (or is occurring) in social innovation. As entrepreneurship has moved from being about personality and serendipity, to 
an increasingly scientized and standardized process (with universal start-up methodologies and practices), a similar shift has occurred in more contemporary understandings of social innovation.

In the past decade, examples of 'hero' social entrepreneurs (and their associated stories of how they addressed social problems and generated social value) were common in the social innovation literature. A leading example is Nobel Prize winner Muhammad Yunus and his work in microfinance. Yet as the shift in entrepreneurial thinking started to occur, coupled with a desire to scale impact, a similar move in the social innovation literature can be observed, towards processes and systems and away from the cult of individual personalities (Elkington and Hartigan, 2008). It has also shifted from market-oriented approaches to innovation and entrepreneurship (and consequently only market-based solutions to social problems) to a greater focus on cross-sector collaborations and broader institutional change (Seelos and Mair, 2017; Van Wijk et al., 2018).

\section{Social Innovation and Inclusive Innovation}

A related concept to social innovation is the notion of inclusive innovation (George et al., 2012; Moulaert et al., 2013). Linked to inclusive growth, inclusive innovation refers to innovations that create or enhance opportunities to improve wellbeing for those at the 'bottom of the pyramid' (BoP). It can include any form of innovation - product, service, business model - and can represent the recombining of existing resources in new ways, or be completely new to a context (George et al., 2012). The issue of extreme inequality facing global society has seen a complementary increase in public policy attention (or at least discourse) on the issue of inclusive growth. Inclusive growth is about improvements in the social and economic prosperity of those members of society who have been 'structurally denied access to resources, capabilities and opportunities' (George et al., 2012, p. 661).

Similar to social innovation, inclusive innovation is often described as referring to both a process and outcome of innovation. However, distinct from social innovation is its focus on removing or overcoming the structural barriers for marginalized or the poorest members of society, those at the bottom of the income pyramid, with many examples focusing on developing-country contexts. This focus on the BoP often sees inclusive innovation transforming the poor into entrepreneurs and being innovative with minimal resources (also referred to as 'frugal innovation') or involves multinational firms in producing products and services appropriate for BoP markets. As for social innovation, the paradoxical 
tension between generating financial and social value, or in this case the tension between growth (economic) and equality (or avoiding harm), persists, making not all efforts of inclusive innovation 'good'. For example, Hall et al. (2012) show the negative impact of government efforts to drive social inclusion through entrepreneurship in examining state-backed tourism developments in Brazil that neglect local history and local craft. Others also note the dark side of inclusive innovation, when multinationals do not understand and as a result disrupt local community relations and social structures, doing more harm than good (for example, see Ansari et al., 2012; Halme et al., 2012).

The discourse on inclusive innovation converges, at this point in time, on removing structural barriers to participation in marketplaces and access to capital for entrepreneurial activities. Scholars note, similarly to social innovation, that any innovations attempting to deliver inclusive growth are created and implemented within a broader institutional system that can both enable or constrain activities and growth. Existing structures, norms, values, sources of legitimacy, and regulatory systems all shape the process and outcome of inclusive innovation. The questions over actually measuring when inclusivity has been achieved are inherently difficult, as is the issue of who is included versus who benefits.

\section{CHAPTER SUMMARY}

It has not been the aim of this chapter to aggregate the many definitions and reviews and deliver an all-compassing definition. A review of the academic and grey literature, across disciplines, has revealed some common characteristics as to understandings of innovation that are useful in developing the construct of social innovation. What it also reveals is the plurality of views and how maintaining this plurality is actually a source of innovation (for example, bringing different voices and values about problem definition and solution to discussions), as well as a necessary part of understanding how problems and solutions are (and may be) worked out across different disciplines and sectors. In this sense, the plurality is to be embraced.

As a construct, there are several well identified elements of social innovation that scholars of social innovation need to be attentive to, based on existing literature: social value, source and significance. Yet extending this, as shown in this review, is a necessary focus on elements' collectivity of process, diversity of actors, and relationality whereby new relational channels or configurations often need to be established; however, the coordinating infrastructure to achieve this is varied, temporary 
and also under-theorized. These elements of social innovation lend themselves to three theoretical lenses of social innovation, appearing with different emphasis.

In each of the following chapters, I explore in detail what I identify as three lenses for theorizing social innovation, with varying ontological positions: social innovation as social value creation, capture and distribution (Chapter 2); social innovation as polysemous and irreducible to a single definition (Chapter 3); and social innovation as institutional change (Chapter 4). As noted in the Introduction, I then conclude with a discussion of how social innovation is a contemporary manifestation of long-examined tension between the economy and society and theorizing of justice and social and economic progress.

In what follows, Chapter 2, I theorize social innovation as social value creation, capture and distribution. Existing bibliometric reviews of social innovation reveal a core citation on value co-production (Ramirez, 1999) anchoring much theorizing on social innovation. This theoretical approach takes a more positivist view of social innovation, in assuming that there can be some objectivity around calculating, measuring and observing value. I draw on key articles from mainstream management and business literature on value creation and capture, and develop the process of value distribution as a way of theorizing social innovation more comprehensively.

\section{NOTES}

1. Chapter 3 explores in greater detail the different perspectives and understandings of each of these societal domains of activity, and what this means for social innovation.

2. Noting that whilst they are common, they are also in need of further exploration, which I do in Chapters 2, 3 and 4.

\section{REFERENCES}

Algoso, D. (2015). Feeling frustrated by your job in development? Become an extrapreneur. The Guardian, 1 September.

Anderson, J. and Markides, C. (2007). Strategic innovation at the base of the pyramid. MIT Sloan Management Review, 49(1), 83-8.

Ansari, S., Munir, K. and Gregg, T. (2012). Impact at the 'bottom of the pyramid': the role of social capital in capability development and community empowerment. Journal of Management Studies, 49(4), 813-42.

Battilana, J. and Lee, M. (2014). Advancing research on hybrid organizing: insights from the study of social enterprises. Academy of Management Annals, 8(1), 397-441. 
Benneworth, P. and Cunha, J. (2015). Universities' contributions to social innovation: reflections in theory \& practice. European Journal of Innovation Management, 18(4), 508-27.

Cajaiba-Santana, G. (2013). Image construction in non-profit organizations: a discursive analysis. Academy of Management Proceedings, 2013(1).

Cajaiba-Santana, G. (2014). Social innovation: moving the field forward. A conceptual framework. Technological Forecasting and Social Change, 82, 42-51.

Campbell, J.L. (2004). Institutional Change and Globalization. Princeton, NJ: Princeton University Press.

Clegg, S.R., Courpasson, D. and Phillips, N. (2006). Power and Organizations. Thousand Oaks, CA: SAGE Publications.

Drucker, P.F. (1987). Social innovation - management's new dimension. Long Range Planning, 20(6), 29-34.

Edwards-Schachter, M. and Wallace, M.L. (2017). 'Shaken, but not stirred': sixty years of defining social innovation. Technological Forecasting and Social Change, 119, 64-79.

Elkington, J. and Hartigan, P. (2008). The Power of Unreasonable People: How Social Entrepreneurs Create Markets that Change the World. Boston, MA: Harvard Business Press.

George, G., McGahan, A.M. and Prabhu, J. (2012). Innovation for inclusive growth: towards a theoretical framework and a research agenda. Journal of Management Studies, 49(4), 661-83.

Hall, J., Matos, S., Sheehan, L. and Silvestre, B. (2012). Entrepreneurship and innovation at the base of the pyramid: a recipe for inclusive growth or social exclusion? Journal of Management Studies, 49(4), 785-812.

Halme, M., Lindeman, S. and Linna, P. (2012). Innovation for inclusive business: intrapreneurial bricolage in multinational corporations. Journal of Management Studies, 49(4), 743-84.

Hargrave, T.J. and Van de Ven, A.H. (2006). A collective action model of institutional innovation. Academy of Management Review, 31(4), 864-88.

Hazel, K.L. and Onaga, E. (2003). Experimental social innovation and dissemination: the promise and its delivery. American Journal of Community Psychology, 32(3-4), 285-94.

Kanter, R.M. (1999). From spare change to real change. The social sector as a beta site for business innovation. Harvard Business Review, 77(3), 122-32.

Lawrence, T.B., Dover, G. and Gallagher, B. (2014). Managing social innovation. In M. Dodgson, D. Gann and N. Phillips (eds), The Oxford Handbook of Innovation Management. Oxford: Oxford University Press, pp. 316-34.

Logue, D. and Grimes, M. (2018). Platforms for the people: the cultivation of institutional infrastructure for social innovation. Working paper.

Logue, D., McAllister, G. and Schweitzer, J. (2017). Social entrepreneurship and impact investing report. Report prepared for innovationXchange, Department of Foreign Affairs and Trade by the University of Technology Sydney. Accessed at: https://www.uts.edu.au/sites/default/files/article/downloads/UTS \%20SEIII\%20Research\%20Report_2017.pdf.

McCarthy, J.D. and Zald, M.N. (1977). Resource mobilization and social movements: a partial theory. American Journal of Sociology, 82(6), 1212-41. 
McGowan, K. and Westley, F. (2015). At the root of change: the history of social innovation. In A. Nicholls, J. Simon and M. Gabriel (eds), New Frontiers in Social Innovation Research. London: Palgrave Macmillan.

Moulaert, F., MacCallum, D., Mehmood, A. and Hamdouch, A. (2013). Handbook of Social Innovation. Cheltenham, UK and Northampton, MA, USA: Edward Elgar Publishing.

Moulaert, F., Martinelli, F., Swyngedouw, E. and Gonzalez, S. (2005). Towards alternative model(s) of local innovation. Urban Studies, 42(11), 1969-90.

Mulgan, G. (2006). The process of social innovation. Innovations, Spring, pp. $145-62$.

Mulgan, G., Tucker, S., Ali, R. and Sanders, B. (2007). Social Innovation: What it is, why it matters and how it can be accelerated. Accessed at: https:// youngfoundation.org/publications/social-innovation-what-it-is-why-it-mattershow-it-can-be-accelerated/.

Mumford, M.D. (2002). Social innovation: ten cases from Benjamin Franklin. Creativity Research Journal, 14(2), 253-66.

Nicholls, A.M. and Murdock, A. (2012). Social Innovation. Blurring Boundaries to Reconfigure Markets. New York: Palgrave Macmillan.

OECD (2000). OECD LEED Forum on Social Innovations. Accessed at: http:// www.oecd.org/fr/cfe/leed/forum-social-innovations.htm.

Olsen, M. and Boxenbaum, E. (2009). Bottom-of-the-pyramid: organizational barriers to implementation. California Management Review, 51(4), 100-125.

Phillips, W., Lee, H., Ghobadian, A., O’Regan, N. and James, P. (2015). Social innovation and social entrepreneurship: a systematic review. Group \& Organization Management, 40(3), 428-61.

Phills, J.A.J., Deiglmeier, K. and Miller, D.T. (2008). Rediscovering social innovation. Stanford Social Innovation Review, 6(4), 34-43.

Pol, E. and Ville, S. (2009). Social innovation: buzz word or enduring term? The Journal of Socio-Economics, 38(6), 878-85.

Porter, M. and Kramer, M. (2011). Creating shared value: how to reinvent capitalism - and unleash a wave of innovation and growth. Harvard Business Review, January-February, 1-17.

Prahalad, C.K. (2012). Bottom of the pyramid as a source of breakthrough innovations. Journal of Product Innovation Management, 29(1), 6-12.

Prahalad, C.K. and Hammond, A. (2002). Serving the world's poor, profitably. Harvard Business Review, 80(9), 48-59.

Ramirez, R. (1999). Value co-production: intellectual origins and implications for practice and research. Strategic Management Journal, 20(1), 49-65.

Randhawa, K., Josserand, E., Logue, D. and Schweitzer, J. (2017). Knowledge collaboration between organizations and online communities: the role of open innovation intermediaries. Journal of Knowledge Management, 21(6), 1293-318.

Rogers, E.M. (1962). Diffusion of Innovation. New York: Free Press.

Seelos, C. and Mair, J. (2017). Innovation and Scaling for Impact: How Effective Social Enterprises do it. Stanford, CA: Stanford University Press.

Selsky, J.W. and Parker, B. (2005). Cross-sector partnerships to address social issues: challenges to theory and practice. Journal of Management, 31(6), 849-73. 
Selsky, J.W. and Parker, B. (2010). Platforms for cross-sector social partnerships: prospective sensemaking devices for social benefit. Journal of Business Ethics, 94(Suppl.), 21-37.

Silveira, F.F. and Zilber, S.N. (2017). Is social innovation about innovation? A bibliometric study identifying the main authors, citations and co-citations over 20 years. International Journal of Entrepreneurship and Innovation Management, 21(6), 459-84.

Swyngedouw, E. (2005). Governance innovation and the citizen: the janus face of governance-beyond-the-state. Urban Studies, 42(11), 1991-2006.

Tilly, C. (2004). Social Movements, 1768-2004. London: Routledge.

Tracey, P. and Stott, N. (2017). Social innovation: a window on alternative ways of organizing and innovating. Innovation, 19(1), 51-60.

Van der Have, R.P. and Rubalcaba, L. (2016). Social innovation research: an emerging area of innovation studies? Research Policy, 45(9), 1923-35.

Van Wijk, J., Zietsma, C., Dorado, S., De Bakker, F.G. and Martí, I. (2018). Social innovation: integrating micro, meso, and macro level insights from institutional theory. Business \& Society.

Voorberg, W.H., Bekkers, V.J. and Tummers, L.G. (2015). A systematic review of co-creation and co-production: embarking on the social innovation journey. Public Management Review, 17(9), 1333-57.

Westley, F. and Antadze, N. (2010). Making a difference: strategies for scaling social innovation for greater impact. Innovation Journal, 15(2), 1-19.

World Economic Forum (2013). Breaking the binary: policy guide to scaling social innovation. WEF. Accessed at: https://www.weforum.org/reports/ breaking-binary-policy-guide-scaling-social-innovation-2013. 